\begin{tabular}{c} 
International Journal of Engineering \& Technology, 6(1) (2017) 9-12 \\
International Journal of Engineering \& Technology \\
SPC \\
Website: $\begin{array}{c}\text { ww.sciencepubco.com/index.php/IJET } \\
\text { doi: } 10.14419 / \text { ijet.v6il.6316 } \\
\text { Research paper }\end{array}$ \\
\hline
\end{tabular}

\title{
Effect of accumulated dust on the performance of solar PV module
}

\author{
Nahar Nahar Nipu *, Avijit Saha, Md. Fayyaz Khan \\ Dept. of Electrical and Electronic Engineering, United International University, Dhaka, Bangladesh \\ *Corresponding author E-mail: nnn.eee016@gmail.com
}

\begin{abstract}
A Solar panel is rated such that it can yield optimum output under Standard Testing Conditions (STC). But due to different environmental factors the efficiency of the panel is reduced gradually after installation. Accumulation of dust on solar PV panel is one such natural phenomenon. When dust accumulates on the PV panel, the temperature of the cells increases which subsequently decreases the open circuit voltage. The short circuit current is also reduced as deposition of dust causes shading on the panel surface. As a result, the output power of the module decreases. In this paper, the effect of dust on the performance of the photovoltaic module has been studied. The increase in temperature due to dust accumulation has been visualized through the thermal camera and the reduction in power has been analyzed through PSpice simulation and experimental data for the different amount of dust accumulated.
\end{abstract}

Keywords: Dust Accumulation; Open Circuit Voltage; Power Degradation; Pspice; STC.

\section{Introduction}

The continuous degradation of the existing fuel reserve and the adverse effects of the climate changes have been imposing great importance on adopting green and renewable energy for the last few decades. Many types of research have been made on various renewable energy sources to meet the rise in consumption and price of fuel. The renewable energy includes tidal, the wind, biomass, geothermal and solar energy production [1], [2]. Most of these technologies are at demonstrative stages but shown promissory results to control greenhouse emissions [3]. Out of these sources solar photovoltaic system is very much popular as nature has bestowed endless amount of solar energy all over the world. However, a reduction in efficiency of a solar PV module during its 25 years life cycle is not at all expected as it takes almost six years for a solar PV module to produce the same amount of energy consumed during its manufacturing period [4]. Therefore, true advantages can only be derived if the system is properly installed and periodically maintained.

A solar PV is basically a p-n junction that converts solar light energy into electrical energy. The output power depends on the available area for transmission of light. This available area for transmission may vary in different environmental conditions. The aim of this paper is to find out how the accumulation of dust affects the performance of solar PV module.

Accumulation of dust plays a vital role in reducing the efficiency of solar PV module. Dust mostly depends on panel inclination, kind of installation, humidity, pollution, wind etc. Low wind can be a cause of dust accumulation whereas high wind does a cleaning action [4]. Air borne dust mainly affects the performance of PV cells [5]. Moreover, the optimum power of a solar PV can be achieved by proper installation of a PV system. Tilted angle should be adjusted to improve efficiency at non-peak hours. Dust accumulation is dependent on the tilt angle. At lower tilt angle higher dust particles can be observed [6].
The increase in temperature is directly proportional to the amount of dust. The more dust accumulates over the panel, higher is the temperature of the module. Higher temperature decreases the open circuit voltage as well as the short circuit current. As the total output power is measured by the $\mathrm{V}_{\mathrm{oc}}$ and $\mathrm{I}_{\mathrm{sc}}$, the output power reduces [8], [9]. So it can be concluded that dust accumulation on solar PV reduces the power to a great extent and so it is very important to study the effects and solutions of dust deposition in module performance measurement.

\section{Previous studies on the impact of dust on solar PV module}

A solar cell works at daytime when solar light incidence on the PV module. The performance of a solar cell increases at the higher light intensity and vice versa.

Dust particle on a solar PV reduces the available transmission area of the incident photons [10]. Scientists are facing a major problem due to sand accumulation. Various researches have worked on this and proved that, more than $50 \%$ of solar PV performance reduces due to uncleaned panels within a period of one month [11], [12].The previous study also indicates that the influence of dust on $\mathrm{PV}$ performance would be higher in spring and summer than in autumn and winter [13].

The leading IT organization Google investigated the impact of dust on flat and a tilted panels of a 1.6 MW solar project in its headquarter in California [14]. After 15 months of installation they came to a conclusion that flat panels are more likely to be affected than tilted panels.

So, it is a proven fact that cleanliness and temperature affect the performance of a solar PV module to a great extent. The clean and cool panel insures higher efficiency [15].

Practically it is very difficult to avoid dust and remain it cool all the day long. This is what makes the study of effects of dust on the performance of the solar PV module a key issue. For the study, 
two identical solar PV modules each consisting of 24 cells having two parallel strings have been used. Then a developed PSpice model has been used to study the effect of dust. The temperature differential has been analyzed with the help of a thermal camera and later on the simulated results have been experimentally validated.

\section{Analytical model of a practical solar cell}

A solar cell is a p-n junction that converts solar light energy into electrical energy. A practical solar cell can be considered as a current generator. The diodes represent the recombination and dark loss. In a practical solar cell there are series resistances due to junction resistance and resistances of the metallic contacts. Again there is shunt loss in the junction surface. Finally, the effect of temperature and solar irradiance are taken into account. Thus, a behavioral model is developed to simulate the performance of a solar cell under different operating conditions [16]:

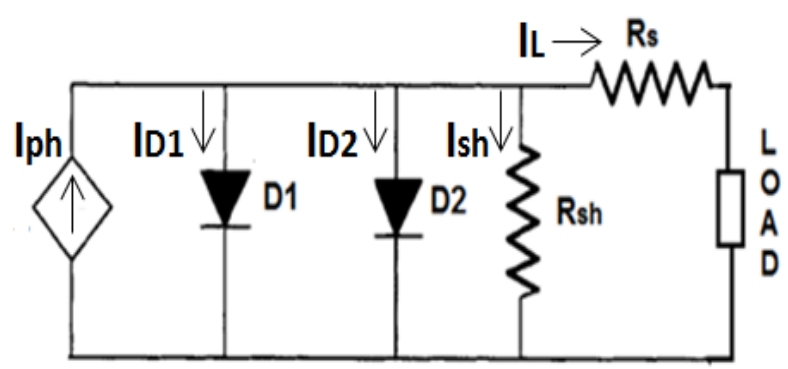

Fig. 1: Equivalent Electrical Circuit of a Practical Solar Cell.

Under the light, solar cell produces a photocurrent which is fed to the load after the losses occur. The load voltage and load current can be calculated using the following formula:

Load Current,

$I_{L}=I_{p h}-I_{D 1}-I_{D 2}-I_{s h}$

Photocurrent,

$\mathrm{I}_{\mathrm{ph}}=\frac{\mathrm{J}_{\mathrm{sc}} \mathrm{AG}}{1000}+\mathrm{AC}_{\mathrm{Isc}}(\mathrm{T}-25)$

Current through photodiode,

$I_{D 1}=A_{0}\left(e^{\frac{V_{L}-I_{L} R_{s}}{n V_{T}}}-1\right)$

Current through recombination diode,

$I_{\text {D2 }}=\mathrm{AJ}_{02}\left(\mathrm{e}^{\frac{\mathrm{V}_{\mathrm{L}}-\mathrm{I}_{\mathrm{L}} \mathrm{R}_{\mathrm{s}}}{\mathrm{nV_{ \textrm {T } }}}}-1\right)$

Current through shunt resistance,

$I_{s h}=\frac{V_{L}-I_{L} R_{S}}{R_{s h}}$

Open circuit voltage,

$\mathrm{V}_{\mathrm{Oc}}=\mathrm{V}_{\mathrm{T}} \ln \left(1+\frac{\mathrm{J}_{\mathrm{Sc}}}{\mathrm{J}_{\mathrm{O}}}\right)$

To find out the parameters of a practical solar cell, some common quantitates used are [16]:

$\mathrm{J}_{\mathrm{sc}}=$ Short circuit current density at $\mathrm{STC}=0.031 \mathrm{~A} / \mathrm{cm}^{2}$

$\mathrm{J}_{0}=$ Saturation current density $=10^{-11} \mathrm{~A} / \mathrm{cm}^{2}$

$\mathrm{J}_{02}=$ Recombination current density $=10^{-9} \mathrm{~A} / \mathrm{cm}^{2}$

$\mathrm{A}=$ Area of the solar cell
$\mathrm{G}=$ Irradiance in $\mathrm{W} / \mathrm{m}^{2}$

$\mathrm{C}_{\mathrm{Isc}}=$ Temp. Co-efficient of short circuit current $=6.4 \times 10^{-6}$

$\mathrm{T}=$ Operating temperature,

$\mathrm{V}_{\mathrm{T}}=$ Thermal voltage $=25 \mathrm{mV}$

$\mathrm{E}_{\mathrm{g}}=$ Band gap energy $=1.17 \mathrm{ev}$

$\mathrm{R}_{\mathrm{s}}=10^{-4} \Omega$

$\mathrm{R}_{\mathrm{sh}}=10^{5} \Omega$

In this paper, to study the effect of dust on solar PV module, a poly-crystalline silicon PV module (Model: SLP2.5-04H) marketed by Solarland Bangladesh with following specifications has been chosen:

Total no. of cells $=24$, Cell Area $=7.5 \mathrm{~cm}^{2}$,

$\mathrm{V}_{\mathrm{oc}}=7.0 \mathrm{~V}, \mathrm{I}_{\mathrm{sc}}=0.46 \mathrm{~A}$,

$\mathrm{V}_{\mathrm{m}}=5.7 \mathrm{~V}, \mathrm{I}_{\mathrm{m}}=0.43 \mathrm{~A}, \mathrm{P}_{\mathrm{m}}=2.5 \mathrm{~W}$.

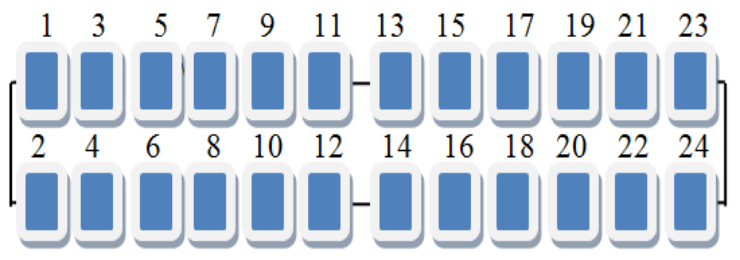

Fig. 2: Schematic of Solar PV Module Chosen for Study.

Taking the required parameters into consideration, a P-Spice model has been developed to simulate the performance of the abovementioned solar PV module. Throughout the paper, the term panel or module will refer to this panel. The P-Spice model gives the following I-V characteristics curve of the module:

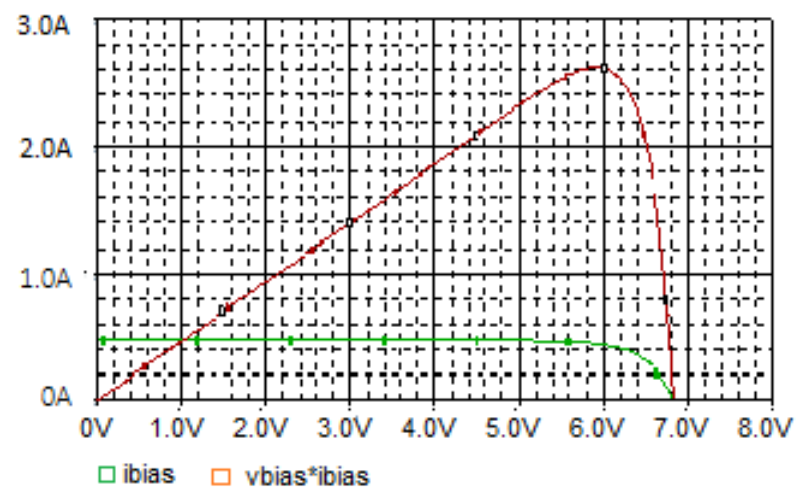

Fig. 3: I-V Characteristics of a $2.5 \mathrm{~W}_{\mathrm{p}}$ Solar PV Module under STC.

(3) Here

$\mathrm{V}_{\mathrm{oc}}=6.85 \mathrm{~V}$,

$\mathrm{I}_{\mathrm{sc}}=465 \mathrm{~mA}$,

$\mathrm{V}_{\mathrm{m}}=6 \mathrm{~V}$,

$\mathrm{I}_{\mathrm{m}}=435 \mathrm{~mA}$

$\mathrm{P}_{\mathrm{m}}=2.6 \mathrm{~W}$.

From Fig. 3, it is evident that the simulated values are slightly different from the given specifications of the panel. This can happen due to various technical reasons including the value of short circuit and recombination current density, series and shunt resistance etc. But this slight deviation has been considered to be acceptable.to carry out the study.

\section{Temperature differential due to dust accu- mulation within one week of installation}

The PSpice model takes cell temperature and irradiance as input to simulate the I-V characteristics curve of the given panel. For this purpose, two identical panels were installed on the rooftop with a 24-degree tilt angle. One of the panels was subjected to continuous dust deposition whereas the other was regularly maintained so that no dust could accumulate on it. After one week, the irradiance was recorded as $900 \mathrm{~W} / \mathrm{m}^{2}$ at an instant. At the same time the in- 
dividual cell temperature of both the clean and dusty panels was measured with an infrared thermometer. For real life visualization, a thermal camera was used to take thermal images of both the panels.

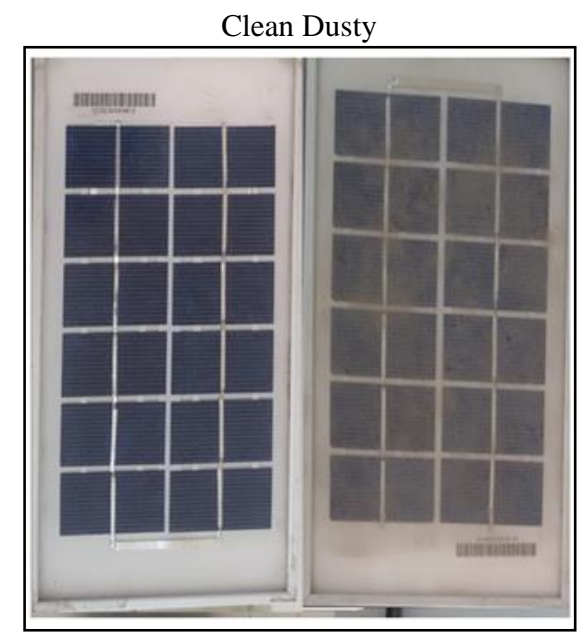

Fig. 4: Visual Image of a Clean and a Dusty Panel.

Temperature Differential Observed through Infrared Thermometer:

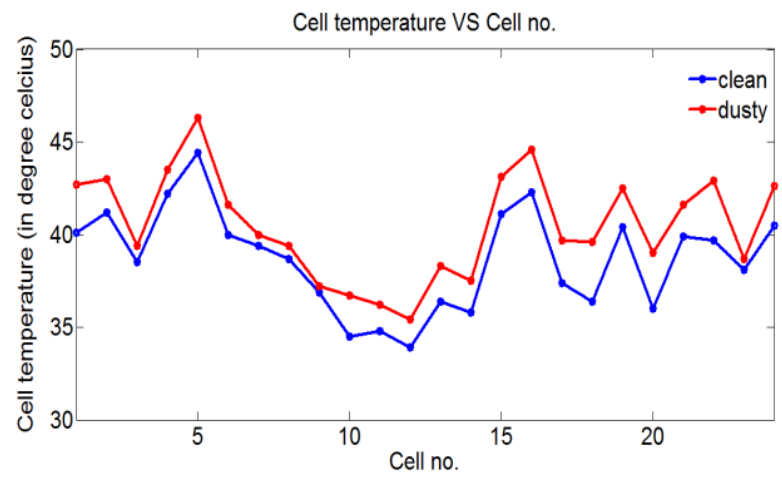

Fig. 5: Temperature Profile of a Clean and a Dusty Panel.

Temperature Differential Observed through DFLIR Thermal Camera:

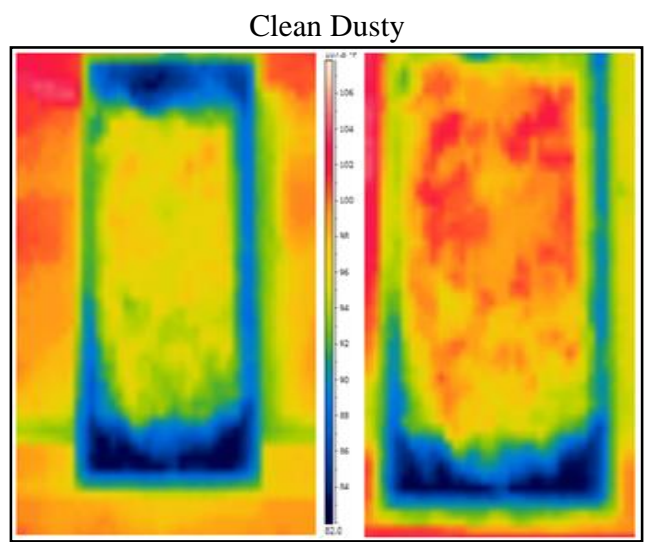

Fig. 6: Thermal Image of a Clean and a Dusty Panel.

From Fig. 5 and 6 it is quite apparent that the temperature of the dusty panel is higher than that of the clean panel.

\section{Performance of solar PV due to dust accu- mulation within one week of installation}

Taking the temperature and irradiance profile as input model, the I-V curve of the PV module have been plotted:
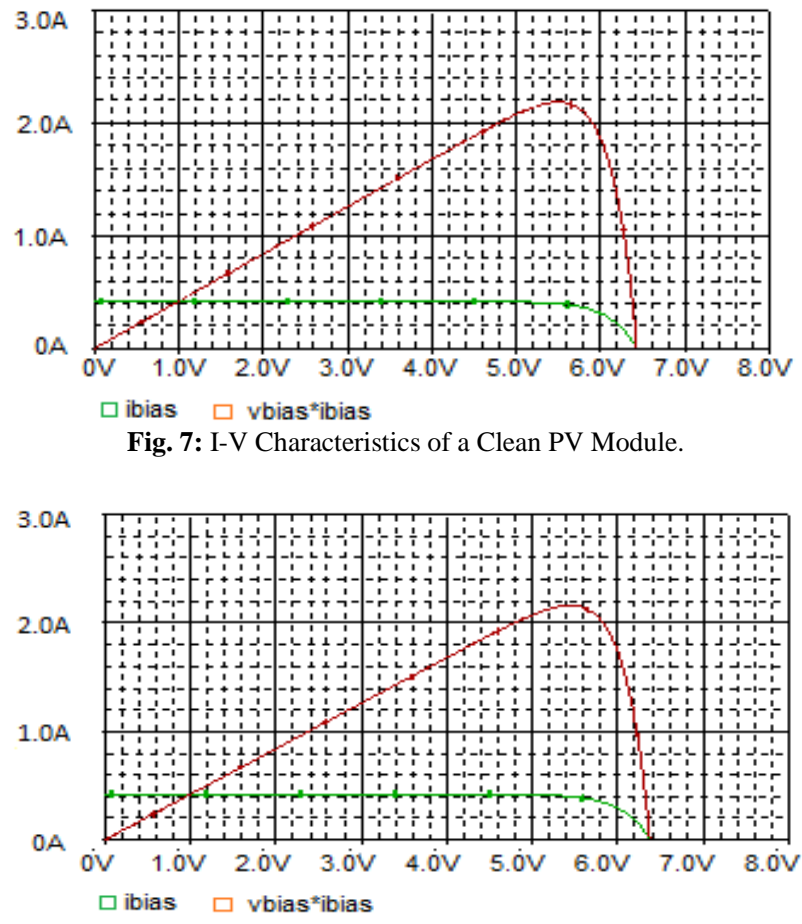

Fig. 8: I-V Characteristics of a Dusty PV Module.

Table 1: Simulated Parameters of a Clean and a Dusty PV Panel after One Week of Installation

\begin{tabular}{lll}
\hline Parameter & Clean Panel & Dusty Panel \\
\hline Avg. Cell Temperature $\left({ }^{\circ} \mathrm{C}\right)$ & 38.68 & 40.69 \\
$\mathrm{~V}_{\mathrm{oc}}(\mathrm{V})$ & 6.42 & 6.37 \\
$\mathrm{I}_{\mathrm{sc}}(\mathrm{mA})$ & 420 & 420 \\
$\mathrm{~V}_{\mathrm{m}}(\mathrm{V})$ & 5.5 & 5.4 \\
$\mathrm{I}_{\mathrm{m}}(\mathrm{mA})$ & 397 & 394 \\
$\mathrm{P}_{\mathrm{m}}(\mathrm{W})$ & 2.18 & 2.13 \\
\hline
\end{tabular}

From Table 1, it can be seen that due to dust accumulation, the overall cell temperature of the dusty panel has increased. The short circuit current is very less affected by an increase in temperature. So, the current is almost the same for both clean and dusty panel. But increase in temperature results in a decrease of open circuit voltage. Therefore, $\mathrm{V}_{\mathrm{oc}}$ of the clean panel is higher than that of the dusty panel. As a result, the maximum power generated by the dusty panel reduces by $2.3 \%$ compared to that of the clean panel.

\section{Performance of solar PV due to dust accu- mulation within one month of installation}

This time the panels were kept on the rooftop for one month. One of the panels was regularly cleaned whereas the other was left uncleaned to accumulate dust. The dusty and the clean panels were connected to a load resistance and by varying the load resistance, the load voltage and load current were measured:

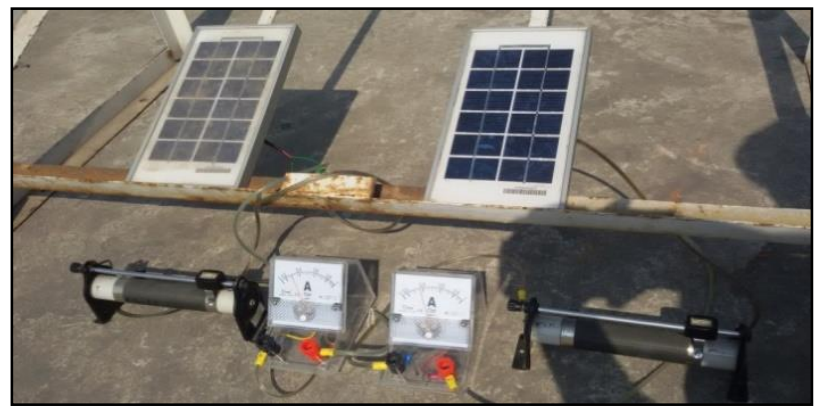

Fig. 9: Experimental Setup for Impact of Dust. 


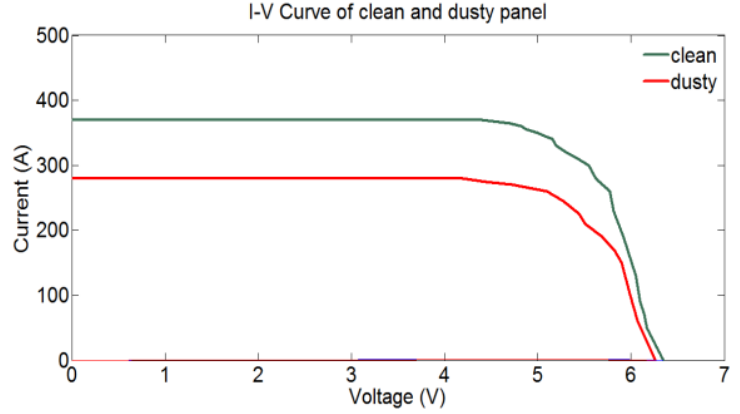

Fig. 10: I-V Curve of a Clean PV Module.

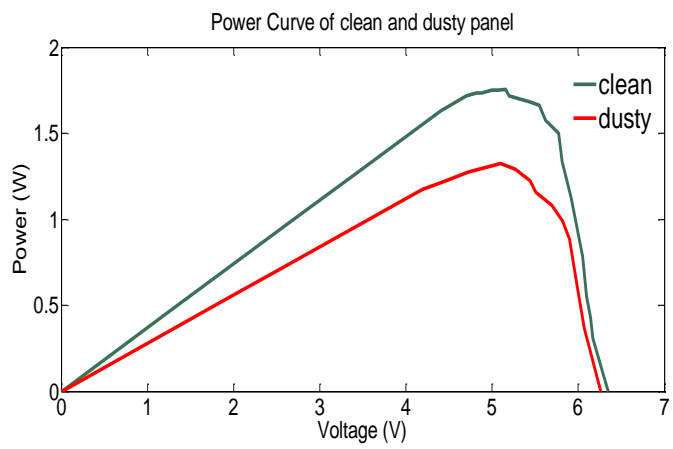

Fig. 11: Power Curve of a Clean PV Module.

Table 2: Experimental Parameters of a Clean and a Dusty PV Panel after One Month of Installation

\begin{tabular}{lll}
\hline Parameter & Clean Panel & Dusty Panel \\
\hline Avg. Cell Temperature $\left({ }^{\circ} \mathrm{C}\right)$ & 34.42 & 37.59 \\
$\mathrm{~V}_{\mathrm{oc}}(\mathrm{V})$ & 6.35 & 6.26 \\
$\mathrm{I}_{\mathrm{sc}}(\mathrm{mA})$ & 370 & 280 \\
$\mathrm{~V}_{\mathrm{m}}(\mathrm{V})$ & 5.16 & 5.10 \\
$\mathrm{I}_{\mathrm{m}}(\mathrm{mA})$ & 350 & 260 \\
$\mathrm{P}_{\mathrm{m}}(\mathrm{W})$ & 1.80 & 1.33 \\
\hline
\end{tabular}

From table 2, it is seen that one month of dust has more impact on a solar panel compared to dust of one week. Here, both the open circuit voltage and short circuit current has reduced by a significant amount resulting in a $26 \%$ reduction in maximum power when compared with a clean panel.

\section{Conclusion}

This paper focuses on the impact of dust accumulation that reduces the output power of a module. The study has been carried out by simulating the I-V characteristics of a solar panel under clean and dusty condition through PSpice software and experimental setup and the main causes that result in poor performance of the solar PV module have been discussed. The overall analysis has been illustrated by experimental data which have been collected under different environmental conditions. The dust increases the temperature of the affected cells, decreases the irradiance thus reduces the output power. The higher is the amount of dust, the higher is the increase in temperature and hence the higher is the reduction in open circuit voltage. Again increased amount of dust reduces the available transmission area of the photons resulting in reduced current generation. That is why in the case of the dust of one month, the performance of the panel has been found even poorer than that of one week. The photovoltaic systems which have small modules are less affected by dust, temperature than that of the systems with larger modules. In the study, it has been also shown that the relative differences in PV module performance parameters between the cases where the modules were dusty and the cases where they are cleaned and unshaded can be higher under the same environmental condition. Therefore, the efficiency can be improved by the proper periodic maintenance of the PV modules. $\mathrm{V}_{\mathrm{oc}}, \mathrm{I}_{\mathrm{sc}}, \mathrm{V}_{\max }, \mathrm{I}_{\max }$ and $\mathrm{P}_{\max }$ are the most affected parameters due to dust and shading which has been found through simulation and experimental data. It is expected that this study is going to be highly beneficial for design engineers responsible for PV system design and implementation.

\section{References}

[1] N. Johnstone, I. Hascic, D. Popp, Renewable energy policies and technological innovation: evidence based on patent counts, Environmental and Resource Economics, 45 (2010) 133-155. https://doi.org/10.1007/s10640-009-9309-1.

[2] M. Esteban, D. Leary, Current developments and future prospects of offshore wind and ocean energy, Applied Energy, 90 ( 2012) 128-130. https://doi.org/10.1016/j.apenergy.2011.06.011.

[3] M. Islam, A. Fartaj, D. S. K. Ting, Current utilization and future prospects of emerging renewable energy application Canada, Renewable and Sustainable Energy Reviews, 8 (2004) 493-519. https://doi.org/10.1016/j.rser.2003.12.006.

[4] R Kannan, K. C. Leong, R. Osman, H. K. Ho and C. P Tso, Life cycle assessment study of solar PV systems: An example of 2.7 KWp distributed solar V system in Singapore, Solar Energy,80 (2006) 555-563. https://doi.org/10.1016/j.solener.2005.04.008.

[5] T. A. Gandhi, A. Gupta., B. V. Shyam, Investigation of the effects of dust accumulation, and performance for mono and polycrystalline silica modules, International Journal of Renewable Energy Research, 4, 3 ( 2014)

[6] D. Gooseen, E.V. Kerchaever, Aeolian dust deposition on photovoltaic solar cells: The effects of the wind velocity and airborne dust concentration on the cell, Solar Energy, 66 (1998) 277-289. https://doi.org/10.1016/S0038-092X(99)00028-6.

[7] A. A. Hegazy, Effect of dust accumulation on solar transmittance through glass covers of plate-type collectors, Renewable Energy, 22 (2001) 525-540. https://doi.org/10.1016/S0960-1481(00)00093-8.

[8] M. Shima, M. Isomura, K. Wakisaka, K. Murata, and M. Tanaka, The influence of operation temperature on the output properties of amorphous silicon-related solar cells, Solar Energy Materials \& Solar Cells, $\quad 85 \quad$ (2005) 167-175. https://doi.org/10.1016/i.solmat.2004.04.016.

[9] S. Nagae, M. Toda, T. Minemoto, H. Takakura, and Y. Hamakawa. Evaluation of the impact of solar spectrum and temperature variations on output power of silicon-based photovoltaic modules, Solar Energy Materials \& Solar Cells, 90 (2006) 3568-3575 https://doi.org/10.1016/j.solmat.2006.06.045.

[10] N. S. Beattie, R. S. Moir, Charlslee Chacko, G. Buffoni, S. H. Roberts, N. M. Pearsalla. Understanding the effects of sand and dust accumulation on photovoltaic modules, Renewable Energy, 48 (2012) 448-452. https://doi.org/10.1016/j.renene.2012.06.007.

[11] B. Marian, J. Adelstein, and others, Performance parameters for grid connected PV system, IEEE. Photovoltaic's specialist conference -Florida, January 3-5 (2005).

[12] J. Bishop, Computer simulation of the effect of electrical mismatches in photovoltaic cell interconnection circuits, Solar Cells, 25 (1988)73-89. https://doi.org/10.1016/0379-6787(88)90059-2.

[13] C. A. Ndiaye M. F. Kebe, P. A. Ndiaye, A. Charki, A. Kobi and V. Sambou, Impact of dust on the photovoltaic (PV) modules characteristics after an exposition year in Sahelian environment: The case of Senegal, International Journal of Physical Sciences, 8, 21(2013) 1166-1173

[14] M. Moon Google Studies: How Dirt Affects Solar Panel Efficiency. PC Magazine: Good Clean tech.

[15] www.goodcleantech.com/2009/08/google_studies_how_dirt_affect. php, accessed 14th November 2015.

[16] A. Abete, E. Barbisio, F. Cane, and P. Demartini, Analysis of photovoltaic modules with protection diodes in presence of mismatching, 21st IEEE Photovoltaic Specialists Conference, (1990) 10051010. https://doi.org/10.1109/PVSC.1990.111769.

[17] L. Castaner, Santiago Silvestre, Modeling photovoltaic systems using PSpice, John Wiley \& Sons, 2002. https://doi.org/10.1002/0470855541.

[18] L.D. Partain, ed. Solar Cells and their applications, 1st edition, John Wiley \& Sons, 1995; 16 